論文

\title{
空港灯火による航空機の地上誘導自動化に関する 数值シミュレーション
}

\author{
正会員 青 木 義 郎* 正会員 谷口哲夫* \\ 正会員 入 倉 隆* \\ Numerical Simulation on Surface Guidance of Aircraft \\ Automated by Airport Light
}

Yoshiro Aoki (Member), Tetsuo Taniguchi(Member),

Takashi Irikura (Member)

(Traffic Safety and Nuisance Research Institute)

\begin{abstract}
A computer program was developed to simulate surface movement of aircraft in an airport. This program can automatically select the shortest route, taking account of the delay caused by the approach between aircraft. The following results were clarified by the use of the program:

(1) Surface movement times calculated for the simulated automatic surface guidance system are not very different from those measured in a real system. The automatic surface guidance system operates as efficiently as a real system operating in the daytime and in good visibility, if block section composition and route selection method are good.

(2) When traffic density is light, the majority of the average aircraft deceleration events in the automatic surface guidance system occur at the taxi holding positions. However, aircraft deceleration occurs frequently even at the stop bar positions other than the taxi holding positions and the total number of aircraft decelerations increases, as traffic density increases. Therefore, availability of stop bar will extend to all areas of airport surface, as traffic density increases.
\end{abstract}

\section{1.まえ がき}

我が国において航空機の利用者数は増加の一途をたどってお $\eta$, 空港での離発着数の增大や就航率向上のための低視程運航の 要求が高まっている。こうしたことから, 航空機のスポットと滑 走路間での空港面誘導は主に管制官とパイロットとの音声連絡を 情報伝達源として行われているが，これに加之て，灯火による視 覚情報に基づいて航空機の地上誘導を制御することが望まれてき ている。

実際に，ヒ一スロ一空港ではストップバー灯や誘導路中心線灯 を空港面全域にめぐらせ，それらを管制官が手動操作によりオン オフ制御させることにより1，航空機同士の安全間隔保持や滑走 路への鿁進入防止，並びに地上走行ルート作成を行っている。 た，成田空港においても一部の誘導路区間でストップバ一灯の手 動操作により交通制御がなされている。

こうして灯火の手動操作により航空機の地上誘導を制御するこ とは, 航空機地上誘導の安全性を高めるものであるが, 一方で管 制官のロードワークを増やすことにもつながる，管制官作業負担 やヒューマンエラーを低減させるためにも，航空機の地上誘導を

*運輸省交通安全公害研究所
計算機により自動化あるいは省力化させていくことが必要である と考之られる。しかしながら，事前に選定された経路に基づく航 空機の走行シミュレーション2や空港配置の性能評価を目的とし た走行シミュレーション3のプログラムの開発及びその実施は試 みられているが, 走行シミュレーションを用いて, 地上走行を自 動化させた時と実走行時との運航効率の比較検討を行ったり, 交 通密度が自動誘導システムに与之る影響を解析した例は見あたら ない。

本研究では，航空機同士の接近によって生じる遅延時間を考虑 した最短経路選択を，Dijkstra 法により随時自動的に行うことが できる地上走行シミュレーションプログラムを開発した4).なお， このシミュレーションプログラムは, 空港レイアウト, 運航スケ ジュ一ル，運航方法の変更が容易に行うことができる。これを用 いて，航空機の地上誘導を空港灯火により自動化させた場合と通 常運用の場合とを比べて運航効率にどのような違いが生じるのか を解析した。また，交通密度が自動誘導システムにおける運航効 率や灯火の運用にどのような影響を及ぼすのかを解析することが できたので，これらの結果について報告する。

\section{2. 航空機の誘導自動化手法}

空港面での航空機の誘導を自動化するためには, (1)検知センサによる航空機の位置情報の収集 
(2)航空機位置情報に基づく最適経路の自動選択 (3)航空機一経路や進行禁止等の走行情報の提供 が必要となる。 (1)、(3)在行うたかのシステム構成を2.1節で, (2)老 行うためのコンピュータによる最適経路選択手法を 2.2 節で述べ る.

\section{1 システム構成}

今回の計算機シミュレーションのモデルとなる誘導路交差点部 での自動誘導システム構成图在 1 に示守。同図に示されるよう に，誘導路を赤色停止灯列であるストップバーにより区切る閉塞 区間を設ける。そして，センサにより各閉塞区間での航空機の有 無を娭知し，それをもとに経路を自動選択亦る。自動選択された 経路は誘導路中心線灯 (緑色進行灯)により，前方閉塞区間への 進行禁止はストップバーにより，パイロットに通知する。

そして，このシステムを空港面全域に広げることにより，空港 面全域での航空機の経路選択者自動化子ることが可能となる。な お，本研究では䣏港面の走行区域について経路選択者自動化する ものとして，その走行状況について計算機シミュレーションを行 i.

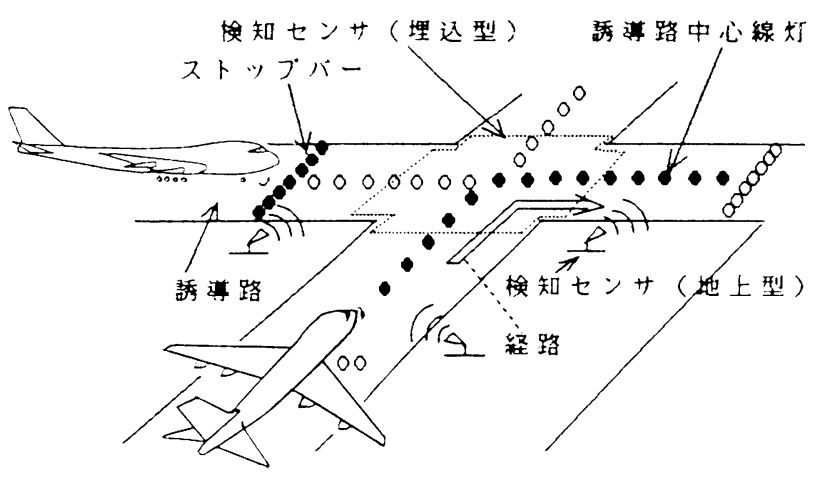

図1自動誘導システ公の構成図

Fig. 1 Composition chart of automatic guidance system.

\section{2 コンピュータによる最適経路選択手法}

経路選択の自動化において最も重要となる現在位置から到着地 点までの最短経路を求める手法は，最適経路選択の代表的な手法 であるDijkstra 法老変形することにより導きだした。

閉塞区間に分割されると，空港の誘導路は，図 2 に示されるよ うにストップバーに相当する閉塞区間境界線が節点，誘導路が枝 となるネットワークで表現できる。そして，誘筫路の形状は， 又 トップバー間老結ぶ誘導路の距離行列 $\mathrm{G}_{\mathrm{ij}}$ で表垷することができ

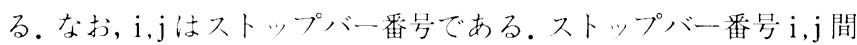
が直接誘導路で結ばれていない場合は距離 $\infty, \mathrm{i}=\mathrm{j}$ の時は距離 0 とする。そして現在位置 L $(0)$ から目的地 L (Last) までの最適経路 は以下の上うにして求める。

(1)空港面に航空機が 1 機しか存在しない場合

推定走行時間行列 $\mathrm{T}_{\mathrm{ij}}=\mathrm{G}_{\mathrm{ij}} / \mathrm{S}_{\mathrm{ij}}$ (ただし， $\mathrm{S}_{\mathrm{ij}}$ はムトップバー 番号 $\mathrm{i}, \mathrm{j}$ 区間にお汁万推定速度行列) を使ってDijkstra 法 ${ }^{5}$ によ $\eta, \mathrm{T}_{\mathrm{L}(0) \mathrm{L}(1)}+\mathrm{T}_{\mathrm{L}(1) \mathrm{L})(2)}+\cdots \cdots+\mathrm{T}_{\mathrm{L}(\text { Last-1)L(Last) }}$ が最小となる経路, 寸なわち現在位置から目的地（離陸機であれば誘導停止位置，着 陸機であればスポットあるいはゲート）までの最短時間経路を選

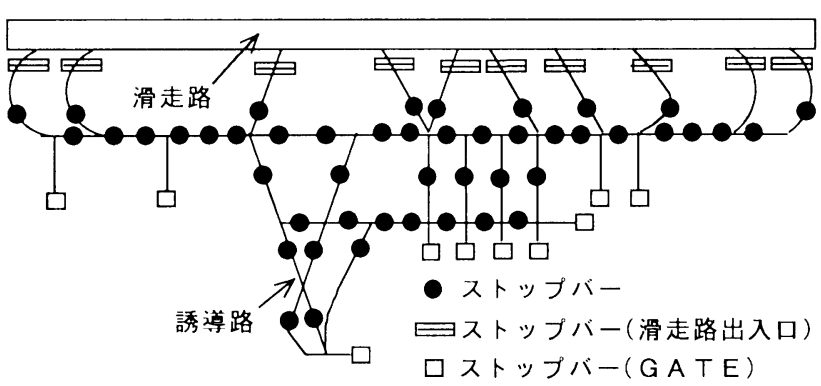

図 2 成等巷誘導路ネ・トワーク図

Fig. 2 Taxiway network chart of Narita airport.

択し，走行スケジュールを作成する。

(2)空港面に航空機が複数 (M機) 存在する場合

航空機がストップバー番号 $\mathrm{L}(\mathrm{N}-1)$ から $\mathrm{L}(\mathrm{N})$ に進行す ると仮定した場合に，その時間中に他の航空機が $\mathrm{L}(\mathrm{N}-1) \rightarrow$ $\mathrm{L}(\mathrm{N})$ に対して走行が許可されない区間（同じ閉塞区間の使用， あるいは交差点がない 1 本の誘導路上での正対走行）に存在する かどうかを起行スケジュールより調べる，存在する場合には，先 行子る航空機に優先権を与之て後行機はその手前で待機させ，そ の走行時の各航空機の走行スケジュ一ルを修正する。そして，そ の走行時に発生するM機分全遅延時間 $\left(\mathrm{t}_{1}+\mathrm{t}_{2}+\cdots \cdots+\mathrm{t}_{\mathrm{M}}\right)$ t, その $\mathrm{i} \rightarrow \mathrm{j}$ 間の推定走行時間 $\mathrm{T}_{\mathrm{L}(\mathrm{N}-1) \mathrm{L}(\mathrm{N})}=\mathrm{G}_{\mathrm{L}(\mathrm{N}-1) \mathrm{L}(\mathrm{N})} / \mathrm{S}_{\mathrm{L}(\mathrm{N}-1) \mathrm{L}(\mathrm{N})}$ に加之て，

$\mathrm{t}_{\mathrm{L}(\mathrm{N}-1) \mathrm{L}(\mathrm{N})}=\mathrm{T}_{\mathrm{L}(\mathrm{N}-1) \mathrm{L}(\mathrm{N})}+\left(\mathrm{t}_{1}+\mathrm{t}_{2}+\cdots+\mathrm{t}_{\mathrm{M}}\right) \times \mathrm{k}$ ただし， $\mathrm{k}=1$ (追従 or 交差)、12(正対).

( $\mathrm{k}$ は各種航空機接近（図4 参照) に対守る重み付计。) とL, $\mathrm{t}_{\mathrm{L}(0) \mathrm{L}(1)}+\mathrm{t}_{\mathrm{L}(2) \mathrm{L}(2)}^{\prime}+\cdots \cdots+\mathrm{t}_{\mathrm{L}(\text { Last-1)L(Last) }}$ が最小となる経 路在Dijkstra 法により選択する。

\section{3. 地上走行シミュレーション実験方法}

本研究では，成田空港を例に，交通密度等により空港面での航 空機の運航効率がどのように変化子るのか走行シミュレーション を行う。

\section{1 航空機の誘導自動化走行シミュレーション手法}

航空機の地上走行シミュレーションのフローチャートを図 3 に 示卞.同四に示さ机る走行経路新規作成や走行経路更新を2.2節に 記述さ㣗ている最適経路選択手法を用いて行うことにより，誘導 在自動化させた時の走行シミュレーションが実施できる。

このシミュレーションの実施により，走行時間及び減速を必要 とする航空機接近回数が解析でき，運航効率についての考察が可 能となる。なお，航空機接近の種類は四 4 に示されるように分類 する。

シミュレーションの時間刻みは 1 秒ごととし，誘導路は図 2 に 示すようなネットワークになるようにストップバーにより 80 300mの閉塞ブロックに分割し, 前方閉塞区間侵入禁止時の減 速開始はストップバー手前 $40 \mathrm{~m}$ 通過時に，経路の新規作成はゲー 卜及び高速離脱誘導路侵入時に, 経路の更新を行う場合にはス卜 ップバー手前 $70 \mathrm{~m}$ 通過時に行うものとする。なお，滑走路の占有 は着陸機が離陸機に優先するものとする。 


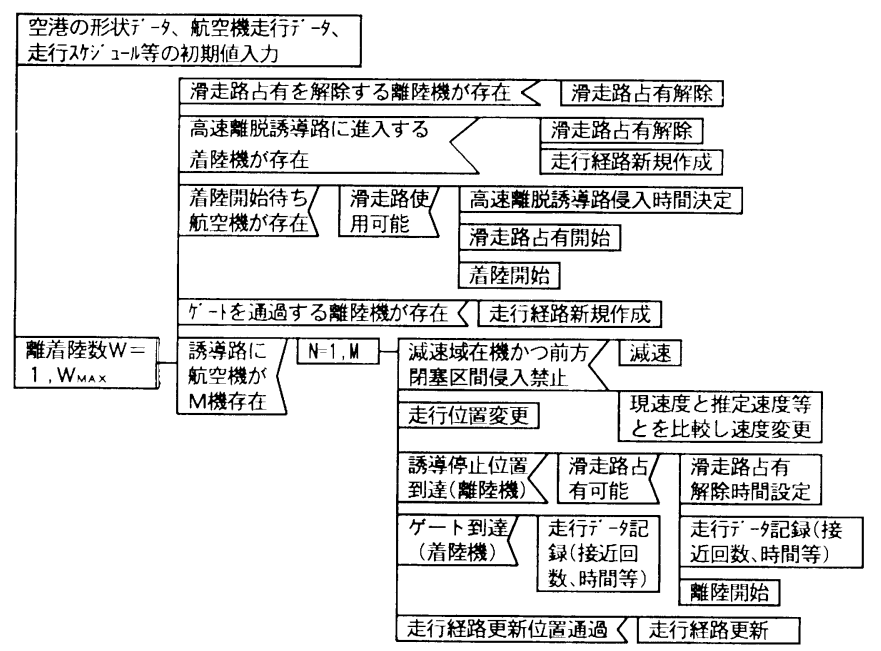

図 3 地上走行シミュレ‥ション基本フローチャ‥ト

Fig. 3 Fundametal flow chart of surface movement simulation.

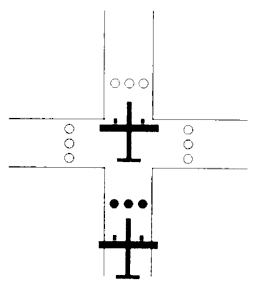

( a ) 追従

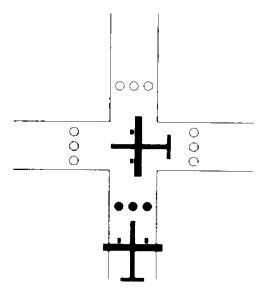

(b) 交差

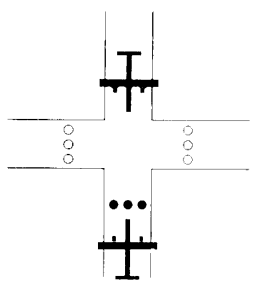

(c) 正対
図 4 航空機接近の種類

Fig. 4 Type of the approach between aircraft.

\section{2 航空機走行データ}

成田空港において，航空機の各区間での走行速度デ一夕をビテ オ撮影により，各区間での走行時間，区間占有時間，スケジュー ル，減速莸伴う航空機接近回数等の走行デー夕を目視観測により 収集した。調查は第 2 夕‥ラルルビルが軍用される前の平成 2 年 8月 1 ～ 3 日の日中に行った。なお，走行シミュレーションもま たそ机に合わせて，第 2 ターミ十ルビルの運用以前に対して解析 を行うものとする。走行スケジュール及び航空機接近回数のサン プルとなる航空機数は240機(離陸機120機, 着陸機120機)で収集 時間は 17 時間，そして，この時の交通密度は平均 17 機/時 ( 1 滑 走路弃たりの，一時間に離発着する航空機数〉，最大時 26 機 / 時で あった。次章に拐いてこの実走行時の走行時間及び航空機接近回 数の結果と誘尊自動化走行シミュレーションの結果とを比較す る。なお，滑走路使用方向は Runway16方向，天気は晴で良視程 な状態であった。

また，本走行シミュレーションを行うのに必要となる各区間で の航空機走行速度を表 1 に，そして誘導路上以外での区間占有時 間在表 2 に示す。

\section{4. 走行シミュレーション結果及び考察}

\section{1 誘導自動化走行と実走行との比較}

日中，良視程時での実走行值，並びに誘導在白動化させた時の
表 1 航空機の走行速度

Table. 1 The speed of taxiing aircraft.

\begin{tabular}{|c|c|}
\hline 移動場所 & 速度 (m/s) \\
\hline 誘導 路 (直線) & $9.6 \pm 2.9$ \\
\hline 誘導 路 (曲線) & $5.8 \pm 1.4$ \\
\hline 高速離脱誘導 & $12.0 \pm 5.0$ \\
\hline
\end{tabular}

注）サンプル数は10〜20

表2 社間与有 (走行) 時間

Table. 2 Section occupation (movemet) time.

\begin{tabular}{|l|c|}
\hline & 時間(秒) \\
\hline 滑走路占有時間 & $110 \pm 20$ \\
\hline 滑走路中央 $->$ 高速離脱 & \\
誘導路入口の走行時間 & $33 \pm 12$ \\
\hline 誘導停止位置 $>$ 滑走路 & \\
中央の走行時間 & $81 \pm 20$ \\
\hline
\end{tabular}

注）サンプル数は18〜 110

地上走行シミュレーション〈以下「自動化シミュレーション」と いう.)計算值をそれぞれ図 5〜7に示寸。図 5 は着陸機に対する 走行時間，図6 洨離陸機に対子る走行時間，図７は各種航空機接 近回数である。なお，走行時間とはゲ一トから滑走路中央までの 走行時間であり，各種航空機接近回数上は全誘導路上での 240 機分 の各種航空機接近回数の総数である。また，自動化シミュレーシ ヨンにおける, 各航空機の離着陸開始時刻, 使用滑走路方向, 各 ゲート及び高速離脱誘導路の使用頻度は奏走行時と同に゙にした。 走行速度の平均值及び標準偏差，誘導路上以外での区間占有時間 は表 1, 表 $2 の$ 半均值及び標準偏差に基づく乱数により与之た。

四 5, 図6に示されるように実走行值と自動化シミュレーショ ン計算值を比較すると，走行時間平均值は非常に近い值を示して おり，走行時間度数分布にも大きな違いは見られなかった。

このことから，閉塞区間の構成方法及び経路選択方法によって は, 誘導老自動化しても運航効率を日中，良視程時の通常走行時 より落とすことなく走行できる可能性があることが推定される。

図 7 に示される航空機接近回数は，自動化シミュレーション計 算值の方が, 追従の場合はやや多く，交差の場合はやや少なくな っている。これは, 実際の走行での減速が, 自動化シミュレーシ ヨンの場合々比べて, 追従の場合には航空機間隔が短い地点で, 交差の場合には航空機間隔が長い地点で開始しているからではな いかと推定される(シミュレーションでの減速開始はストップバ 一手前 $40 \mathrm{~m}$ 通過時).

\section{2 交通密度が運航効率や各ストップバーの運用に与える影} 響

航空機の地上誘導を自動化させる場合，他の航空機や占有中の 滑走路に接近中の航空機は，誘導路全域に設置されたストップバ 一の赤色停止信号を見て減速そして停止を行う。この上うに地上 


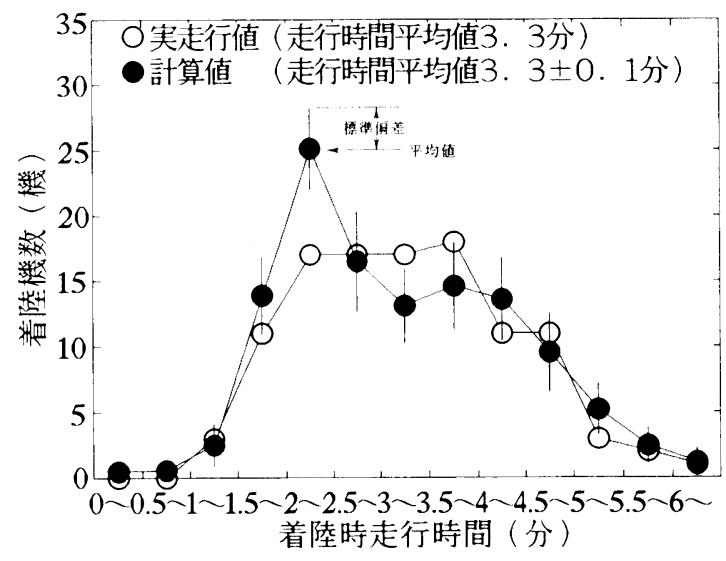

図 5 着陸時走行時間度数分布

Fig. 5 Frequency distribution of surface movement time of the arriving aircraft.

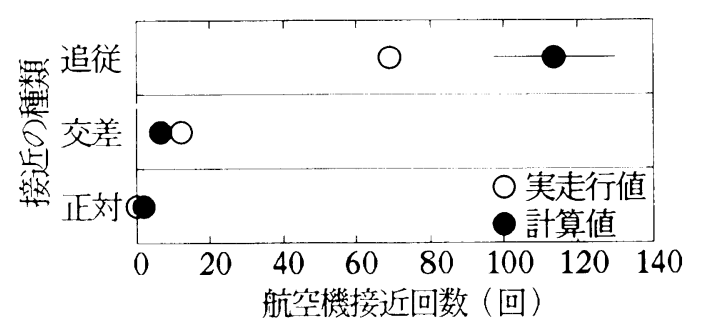

図 7 航空機接近回数

Fig. 7 The number of the approach between aircraft.

誘導を自動化させた場合の各ストップバー位置での赤色停止信号 に上万平均航空機減速回数老図 8 , 全誘導路での平均航空機減速 回数を図 9, 全誘導路での減速や待ち時間によって生じる平均走 行遅延時間を図10に示古。なお，シミュレーションは40,000機分， 離陸機と着陸機の割合は 1：1, 着陸方向は, 16 万向：34万向=

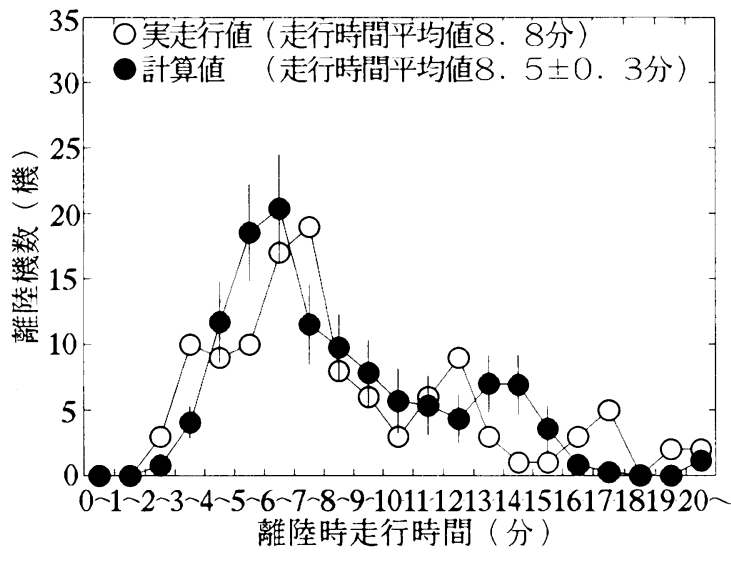

図 6 離陸時走行時間度数分布

Fig. 6 Frequency distribution of surface movement time of the departing aircraft.

1：1と子る。また, 誘導停止位置（滑走路入り口部分の誘導路 の停止位置)では離着陸機により滑走路占有中でなくても，航空 機は一時停止することになっているが，この場合は減速回数に含 めないものとした。

四 8 〜困 9 に示されるように, 交通密度が低い場合には, ス卜 ップバーの赤色停止信号による航空機 1 機あたりの平均減速回数 のうち, その多くは誘導停止位置で占められ, 交通密度が10（機／ 時）の時には誘導停止位置での占有率が約 $50 \%$ 近くにまで達して いる。しかしながら，交通密度が高くなるにつれ，こうした減速 は誘導停止位置以外でのストップバ一位置でも数多く起こるよj になり，その分布は誘導路全域に広がっていき，全体での減速回 数もまた増大していく。したがって，ストップバーの有効性は交 通密度が高いほど空港面全域に広がっていく。

また, 平均走行遅延時間についても, 交通密度が低い場合には, その多くは誘導停止位置で占められるが，交通密度が高くなるに つれ, 誘導停止位置以外でのストップバ一位置でも多くなること が図10に示されている。

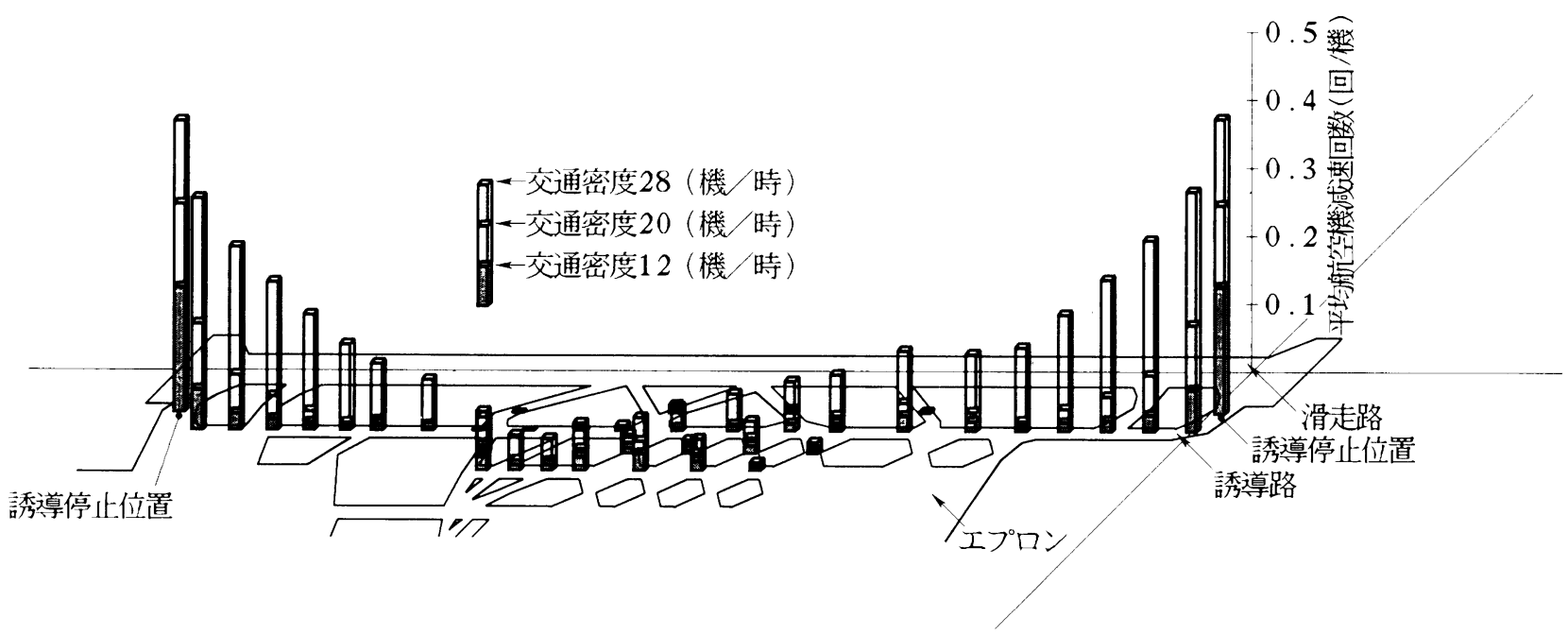

図 8 自動誘導システムにおける各ストップバー位置での平均航空機減速回数

Fig. 8 Average aircraft deceleration frequency at each

stop bar position in the automatic quidance system. 


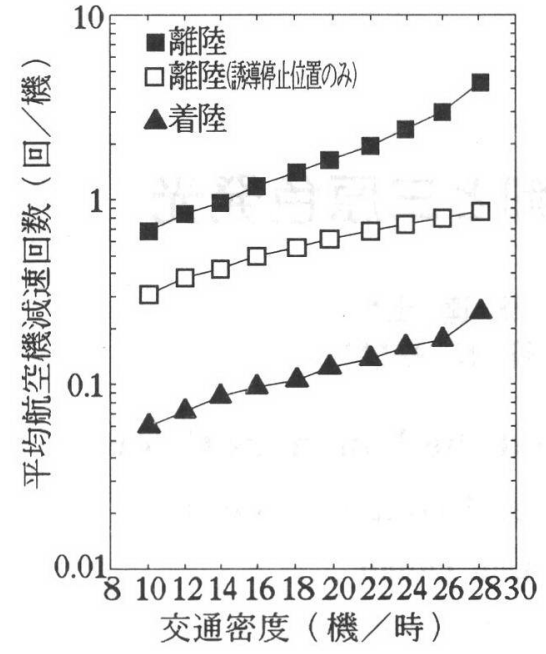

図 9 全誘導路上での平均航空機減速回数

Fig. 9 Average aircraft deceleration frequency on all taxiways.

\section{5.まと め}

本研究では，航空機同士の接近によって生じる遅延時間を考慮 した最短経路選択を，Dijkstra 法により随時自動的に行うことが できる地上走行シミュレーションプログラムを開発した。これを 用いて，空港面に灯火や航空機センサを張り巡らせて閉塞区間を 作成し航空機の地上誘導を自動化させた場合と，日中，良視程時 の実走行の場合とを比べて運航効率にどのような違いが生じるの かを解析した。また，交通密度が自動誘導システムにおける運航 効率や灯火の運用にどのような影響を及ぼすのかを解析した。そ の結果, 以下のことが明らかになった。

（1）実走行値と自動化シミュレーション計算值とを比較すると, 走行時間に大きな違いはない，閉塞ブロックの構成方法及び経 路選択方法によっては, 誘導を自動化することにより, 運航効 率を日中，良視程時の従来の走行時より落とすことなく走行で きる可能性がある。

（2）交通密度が低い場合には，自動誘導システムにおける航空機 1 機あたりの平均減速回数のうち，その多くは誘導停止位置で

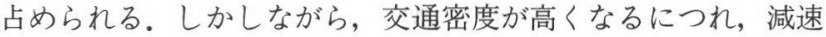
は誘導停止位置以外でのストップバ一位置でも数多く起こるよ うになり，全体での減速回数もまた増大していく。したがって， ストップバー灯の有効性は交通密度が高いほど空港面全域に広 がっていく.

今後も, ’さらに空港の形状, 運航方法, 視程, スケジュール等 と運航効率との関係について詳細な解析を行っていきたい.

\section{参 考 文 献}

（1）照明学会，走行援助灯火システム調查特別研究委員会：走行援助 用灯火システム調查報告書 $(1986)$

(2) 航空振興財団：新東京国際空港の誘導路およびエプロンにおけ る航空機誘導システムの調査研究（そのIII）（1975）

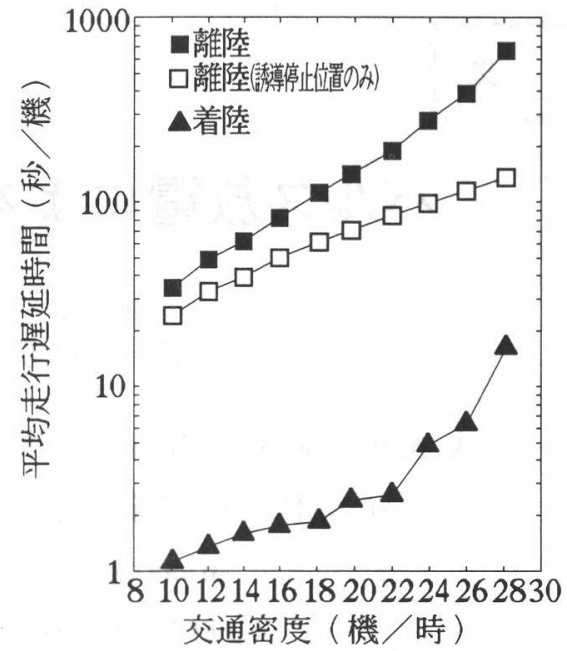

図10 全誘導路上での平均航空機走行遅延時間

Fig.10 Average delay time of taxiing aircraft on all taxiways.

(3) Thomet, M.A. : The Aircraft Movement Simulation Model, Proceeding of the 1983 Winter Simulation Conference pp.641-646(1983)

（4）青木他：空港面における航空機の経路選択自動化シミュレーシ ヨン, 交通安全公害研究所研究発表会(1991)

（5）伊理他：ネットワーク理論，日科技連 (1976) （受付日1993年11月10日／採録日1994年 1 月 18 日）

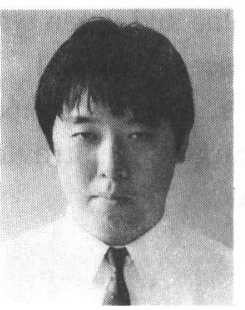

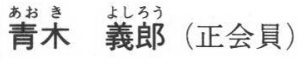

昭和 39 年 12 月 13 日生まれ。昭和 62 年 3 月横浜国立 大学工学部電気光学科卒業。昭和 63 年 4 月運輸省交 通安全公害研究所入所, 現在に至る。航空照明の研 究に従事. 日本シミュレーション学会会貝.

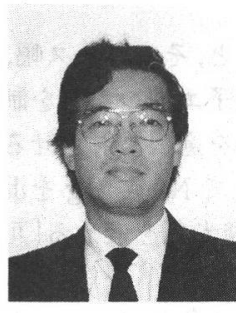

谷口势哲夫 (正会員)

昭和 24 年 9 月 28 日生まれ。昭和 51 年 3 月富山大学 大学院工学研究科機械工学修士課程修了. 航空照明 の研究に従事. 日本機械学会会員.

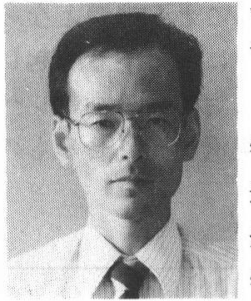

入倉隆 (正会員)

昭和 31 年 5 月 12 日生まれ。昭和 54 年 3 月早稲田大 学理工学部電気工学科卒業. 昭和 57 年 4 月運輸省交 通安全公害研究所入所, 現在同研究所主任研究官. 航空照明の研究に従事. 日本光学会会員, 北米照明 学会会員。 